\title{
Monitoring of essential and heavy metals in green tea from different geographical origins
}

\author{
Justyna Brzezicha-Cirocka • Malgorzata Grembecka • \\ Piotr Szefer
}

Received: 26 May 2015 / Accepted: 3 February 2016/Published online: 22 February 2016

(C) The Author(s) 2016. This article is published with open access at Springerlink.com

\begin{abstract}
The present study measured the concentrations of toxic metals $(\mathrm{Cd}, \mathrm{Pb})$ and other elements $(\mathrm{Ca}$, $\mathrm{K}, \mathrm{Mg}, \mathrm{Na}, \mathrm{P}, \mathrm{Mn}, \mathrm{Fe}, \mathrm{Zn}, \mathrm{Cu}, \mathrm{Co}, \mathrm{Cr}, \mathrm{Ni}$ ) in tea leaves and their infusions. The total metal contents were determined by atomic absorption spectrometry. Phosphorus concentration was determined using an ultraviolet-visible spectrophotometer. Assessment of the mineral composition enabled determination of the leaching percentage and the risk of exceeding provisional tolerable weekly intake for $\mathrm{Cd}$ through daily tea consumption. The concentrations of bioelements were analyzed based on the recommended daily intake values for each. According to recently established standards, green tea was found to be a rich source of $\mathrm{Mn}$. The average $\mathrm{Pb}$ and $\mathrm{Cd}$ levels in a $200-\mathrm{mL}$ beverage were 0.002 and $0.003 \mathrm{mg}$, respectively. Indian teas had the highest percentage of Cd leaching (43.8 \%) and Chinese tea had the lowest (9.41\%). Multivariate analysis techniques such as factor analysis and cluster analysis were used to differentiate samples according to geographical origin (China, India, or Japan). Potassium, $\mathrm{P}, \mathrm{Mn}, \mathrm{Fe}, \mathrm{Cu}, \mathrm{Co}$, and $\mathrm{Cd}$ were effective descriptors for the identification of tea samples from China, India, and Japan.
\end{abstract}

Keywords Green tea $\cdot$ Heavy metals $\cdot$ PTWI $\cdot$ Factor analysis · Cluster analysis

\footnotetext{
J. Brzezicha-Cirocka $\cdot$ M. Grembecka $(\bowtie) \cdot$ P. Szefer Department of Food Sciences, Medical University of Gdansk, Al. Gen. J. Hallera 107, Gdansk 80-416, Poland e-mail: mgrembecka@gumed.edu.pl
}

\section{Introduction}

Tea is one of the most popular beverages in the world mainly because of its pleasant aroma, flavor, and potential positive effect on mood. It has the second position in the ranking of the most widely consumed beverages (Shen and Chen 2008). China is the leading producer of tea in the world, with 1,726,023 tons produced in 2011 (FAOSTAT 2014). Other countries producing large quantities of tea include India, Kenya, and Sri Lanka (FAOSTAT 2014).

Camellia sinensis is the main source of tea leaves, and the quality of tea depends on its cultivation conditions, the soil in which it grows, the degree of contamination, and numerous meteorological conditions.

Recently, there has been observed a growing interest in green tea. Tea antioxidant properties are due to various compounds that prevent Alzheimer's disease, hypertension, and obesity (McKenzie et al. 2010). Besides many biologically active substances such as polyphenols and tannins (Szymczycha-Madeja et al. 2012), tea also contains bioelements as well as toxic metals such as cadmium $(\mathrm{Cd})$ and lead $(\mathrm{Pb})$. These two metals cause permanent damage to key enzymes and many systems of the body including the circulatory, renal, and central nervous ones (Santos et al. 2013). Therefore, it is important to monitor the concentration of these metals, especially in view of permissible limits for growth and good health.

Considering that tea is consumed as a beverage, the percentage of metals leaching into infusions needs to be estimated. Based on the mineral composition of teas, it 
is possible to estimate the permissible limits for heavy metals and the health hazards associated with their intake. Determining the provisional tolerable weekly intake (PTWI) for Cd is critical. Additionally, assessment of the composition of bioelements against their recommended dietary allowance (RDA) for an adult person is important information, not only for dietitians but also for consumers.

Assessment of the concentrations of elements in the different teas enabled their differentiation according to mineral composition and their classification according to geographical origin. It was performed using chemometric techniques that allow on confirmation of food authenticity in view of its composition (Herrador and González 2001; Fernández et al. 2002; Moreda-Piñeiro et al. 2003; Szefer 2007). Among many compounds that can be used to verify the origin and quality of food products are bioelements that usually reflect the soil composition as well as influence of environmental factors. They can also be used as markers of the level of technological processing which was applied to the products. In the literature, there can be found many examples of multivariate techniques of application to such food product analyses such as tea, fruits, honey, virgin olive oils, nuts (pistachios), and many others (Szefer 2007; McKenzie et al. 2010; Grembecka and Szefer 2013a, b; Karabagias et al. 2013; Sciubba et al. 2014).

In case of tea of one type, for instance green, it is important to find factors which will be helpful in its discrimination, i.e., that will reflect the variations resulting from different origins. Therefore, mineral composition is a better choice than organic compounds, which mainly depend on technological processing, and are more suitable to differentiate particular kinds of tea, i.e., green from black (Moreda-Piñeiro et al. 2003).

Herrador and González (2001), Moreda-Piñeiro et al. (2003), and McKenzie et al. (2010) studied mineral composition of tea using modern chemometric methods, which confirmed the differentiation of individual types of teas. Herrador and González (2001) differentiated black, green, and oolong teas by principal component analysis (PCA), cluster analysis, and linear discriminant analysis (LDA) and artificial neural networks trained by back propagation. McKenzie et al. (2010) also conducted chemometrical analysis of various kinds of tea, i.e., white, green, black, oolong, and Pu-erh, based on their mineral composition. Moreover, Moreda-Piñeiro et al. (2003) confirmed, using multivariate techniques that the classification of teas originating from Africa and Asia in view of their country of origin and authenticity is also possible.

In our study, there were also applied chemometric techniques, which were designed to diversify samples of one type of tea, i.e., green tea, and it was possible to confirm the geographical origin of samples based on their mineral composition. Such research is becoming more and more important in view of the introduction of the Regulation of the European Parliament and of the Council (EU) No 1169/(2011) of 25 October 2011 on the provision of information to consumers about food, which requires country of origin information on the product label (Regulation (EU) No 1169/2011). However, few manufacturers provide this information.

In the present study, we analyzed and compared the concentrations of mineral nutrients and toxic metals in 41 green teas, including their infusions, from different geographic regions (China, India, Japan, and others) obtained from the local market. The health benefits and hazards associated with green tea consumption were estimated in view of permissible dietary limits. Evaluation of elemental composition allowed on quantitative differentiation of green tea samples in view of their geographical provenance.

\section{Materials and methods}

\section{Samples}

All teas in loose form and tea bags were chosen to represent the variety of green tea products available on the market in Poland. They were purchased from various tea shops (tea of certified origin) and markets (marketed tea). The characteristics of green tea species are summarized in Table 1. In total, 41 types of green tea were tested and approximately 500 analytical samples were prepared.

\section{Preparation of samples}

The procedure concerning preparations of samples was adopted from Grembecka et al. (2007) with modifications. Firstly, tea was homogenized, using an electric grinder (IKA ${ }^{\circledR}$ A-11 basic), and then 10.0-g $( \pm 0.0001 \mathrm{~g})$ portions were weighed and transferred to quartz crucibles. The first part of mineralization was conducted in an electric furnace using a temperature gradient with a maximum temperature of $540{ }^{\circ} \mathrm{C}$. Subsequently, 
Table 1 Characteristics of the analyzed products

\begin{tabular}{|c|c|c|c|c|}
\hline Lp. & Name of tea & Producer & Country/producer declaration & Confection \\
\hline \multicolumn{5}{|c|}{ Original tea } \\
\hline 1. & Ch. Green Yunnan & Time to tea & China & Loose \\
\hline 2. & Yunnan Green & Five'oclock & China & Loose \\
\hline 3. & China Yunnan & Maraska & China & Loose \\
\hline 4. & ChunMee $^{\mathrm{a}}$ & Manhattan & China & Loose \\
\hline 5. & ChunMee $^{\mathrm{a}}$ & Maraska & China & Loose \\
\hline 6. & Grunpowder $\mathrm{TOH}^{\mathrm{a}}$ & Five'oclock & China & Loose \\
\hline 7. & Grunpowder $\mathrm{TOH}^{\mathrm{a}}$ & Manhattan & China & Loose \\
\hline 8. & Grunpowder $\mathrm{TOH}^{\mathrm{a}}$ & Maraska & China & Loose \\
\hline 9. & Dajreeling Arya & Five'oclock & India & Loose \\
\hline 10. & Darjeeling Green & Time to tea & India & Loose \\
\hline 11. & Japan Bancha ${ }^{\mathrm{a}}$ & Five'oclock & Japan & Loose \\
\hline 12. & Japan Sencha ${ }^{\mathrm{a}}$ & Time to tea & Japan & Loose \\
\hline 13. & Japan Bancha ${ }^{a}$ & Maraska & Japan & Loose \\
\hline 14. & Japan Kokeicha & Five o'clock & Japan & Loose \\
\hline 15. & Kokeicha & Manhattan & Japan & Loose \\
\hline 16. & Japan Sencha ${ }^{\mathrm{a}}$ & Manhattan & Japan & Loose \\
\hline 17. & Japan SenchaFukuyu & Five'oclock & Japan & Loose \\
\hline \multicolumn{5}{|c|}{ Marketed tea } \\
\hline 18. & Green-Pure Green & Irving & China & Bags \\
\hline 19. & Green Grunpowder & Malwa & China & Loose \\
\hline 20. & Green Original China Tea & Sir Roger & China & Loose \\
\hline 21. & Green TeaSencha & Sir William's & China & Bags \\
\hline 22. & Green Tea ${ }^{\mathrm{a}}$ & Teekanne & China & Bags \\
\hline 23. & Green Tea $^{\mathrm{a}}$ & Biofix & China & Loose \\
\hline 24. & Green Tea ${ }^{a}$ & Yunnan & China & Loose \\
\hline 25. & Green Tea $^{\mathrm{a}}$ & Malwa & China & Bags \\
\hline 26. & Green $^{\mathrm{a}}$ & Irving & China & Loose \\
\hline 27. & Pure Green Tea & Twinings of London & China & Loose \\
\hline 28. & Zen Chai & Teekanne & China & Bags \\
\hline 29. & Green TeaOrganic & Darvilles of Windsor & India & Bags \\
\hline 30. & Natural Green Tea & Tarlton & India & Bags \\
\hline 31. & Intensive Green Tea & Telety & Kenia & Bags \\
\hline 32. & Green Tea Pure Green & Dilmah & Sri Lanka & Bags \\
\hline 33. & Ceylon Green Tea & Dilmah & Sri Lanka & Bags \\
\hline 34. & Green Tea Nature & Lipton & - & Bags \\
\hline 35. & Grunpowder Green Tea & Twinings & - & Loose \\
\hline 36. & Green Tea ${ }^{\mathrm{a}}$ & Posti & - & Loose \\
\hline 37. & Leafy Green Tea & Vitax & - & Loose \\
\hline 38. & Green Tea ${ }^{a}$ & Saga & - & Bags \\
\hline 39. & Green Tea $^{\mathrm{a}}$ & Vitax & - & Bags \\
\hline 40. & The Green Leaf & Herbapol & - & Loose \\
\hline 41. & Green $^{\mathrm{a}}$ & Herbapol & - & Bags \\
\hline
\end{tabular}

${ }^{a}$ various producers of tea under the same name 
$1.50 \mathrm{~mL}$ of $36 \% \mathrm{HCl}$ (Tracepure, Merck, Darmstadt, Germany) and two to three drops of $63 \% \mathrm{HNO}_{3}$ (Tracepure, Merck) were added to ashes and evaporated to dryness on a water bath. Then, again, $1.50 \mathrm{~mL}$ of $36 \% \mathrm{HCl}$ was added to residues, which underwent evaporation for $1 \mathrm{~min}$ under a watch glass. Afterward, the resulting solution was transferred to $25-\mathrm{mL}$ flasks with ultrapure water $\left(18 \mathrm{M} \Omega \mathrm{cm}^{-1}\right)$ from a Mili-Q system (Millipore, MA, USA).

Tea infusions were prepared using $2.00 \mathrm{~g}( \pm 0.0001 \mathrm{~g})$ of material and $200 \mathrm{~mL}$ of water in a $250-\mathrm{mL}$ beaker. Tea was infused for $5 \mathrm{~min}$ and then it was filtered through a fluted paper filter. The resulting filtrate, which was transferred to a quartz crucible, was evaporated to dryness on a boiling water bath and the dry residue was ashed in a furnace following the same procedure as that used for the dry sample (Grembecka et al. 2007).

\section{Analyses of elements}

The concentrations of elements $(\mathrm{Ca}, \mathrm{K}, \mathrm{Mg}, \mathrm{Na}, \mathrm{P}, \mathrm{Mn}$, $\mathrm{Fe}, \mathrm{Zn}, \mathrm{Cu}, \mathrm{Co}, \mathrm{Cd}, \mathrm{Cr}, \mathrm{Ni}, \mathrm{Pb}$ ) were determined by atomic absorption spectrometry with flame air-acetylene using the deuterium background correction. The analysis was performed using Thermo Scientific's i3000. Cesium chloride (Cesium chloride, Merck), which acts as an ionizing buffer that shifts the equilibrium of the reaction to generate free atoms of the analyzed element
$(0.2 \% w / v)$, was added to the samples in order to analyze $\mathrm{K}$ and $\mathrm{Na}$ content (Grembecka et al. 2007). Ca and $\mathrm{Mg}$ were analyzed by addition of $0.4 \% \mathrm{w} / \mathrm{v}$ lanthanum oxide (Lanthanum (III) oxide, Merck), which is a correction buffer that allows binding of the analyzed element to a matrix. Phosphorus was determined using a spectrophotometric method (AOAC 2002) with an ultraviolet-visible spectrophotometer (Spekol 11, Carl Zeiss, Jena, Germany) .

The limits of detection (LODs) and the limits of quantification (LOQs) of the applied method were calculated using formulas proposed by Konieczka and Namieśnik (2009), i.e., LOD=blank mean +3 SD and LOQ $=3 \times$ LOD (Table 2) (Grembecka and Szefer 2013a). The reproducibility of the method was assessed using the certified reference material (tea, NCS ZC73014), which was digested using the same procedure as that used for tea samples. The results of the measurement of toxic metals and bioelements in the reference material are summarized in Table 2, which shows that the estimated element recovery and RSDs were satisfactory.

Statistical analysis

Decision of the type of statistical analyses used, parametric and non-parametric, was made after application of the normality Shapiro-Wilk test

Table 2 Validation data of the analytical methodology

\begin{tabular}{llllllll}
\hline Element & Linearity & & & $\begin{array}{l}\text { LOD } \\
(\mathrm{mg} / 100 \mathrm{~g})\end{array}$ & $\begin{array}{l}\text { LOQ } \\
(\mathrm{mg} / 100 \mathrm{~g})\end{array}$ & RSD (\%) & Recovery (\%) \\
\cline { 2 - 5 } & Calibration curve range $(\mu \mathrm{g} / \mathrm{mL})$ & Calibration curve & $\mathrm{R}^{2}$ & & & & \\
$\mathrm{Ca}$ & $2.00-15.0$ & $y=0.05801 x+0.0089$ & 0.999 & 0.020 & 0.060 & 4.42 & 86 \\
$\mathrm{~K}$ & $0.50-1.50$ & $y=0.00048 x+0.0149$ & 0.997 & 0.040 & 0.120 & 4.81 & 102 \\
$\mathrm{Mg}$ & $0.10-0.90$ & $y=0.00107 x+0.0220$ & 0.998 & 0.020 & 0.060 & 1.60 & 96 \\
$\mathrm{Na}$ & $0.50-1.20$ & $y=0.00071 x+0.0192$ & 0.996 & 0.020 & 0.060 & 10.0 & 98 \\
$\mathrm{P}$ & $0.10-1.20$ & $y=0.00444 x+0.0117$ & 0.999 & 0.030 & 0.090 & 0.11 & 103 \\
$\mathrm{Mn}$ & $0.15-5.00$ & $y=0.00015 x+0.0058$ & 0.999 & 0.020 & 0.060 & 0.87 & 92 \\
$\mathrm{Fe}$ & $1.00-10.0$ & $y=0.00006 x+0.0082$ & 0.996 & 0.010 & 0.030 & 5.73 & 101 \\
$\mathrm{Zn}$ & $0.20-1.50$ & $y=0.00034 x+0.0079$ & 0.998 & 0.020 & 0.060 & 0.51 & 100 \\
$\mathrm{Cu}$ & $0.50-4.00$ & $y=0.00013 x+0.0022$ & 0.999 & 0.009 & 0.027 & 0.12 & 91 \\
$\mathrm{Co}$ & $1.00-5.00$ & $y=0.00008 x+0.0052$ & 0.999 & 0.003 & 0.009 & 11.1 & 95 \\
$\mathrm{Cd}$ & $0.20-2.00$ & $\mathrm{y}=0.00035 x+0.0040$ & 0.999 & 0.003 & 0.009 & 10.3 & 97 \\
$\mathrm{Cr}$ & $0.20-2.00$ & $y=0.00005 x+0.0007$ & 0.999 & 0.001 & 0.003 & 4.51 & 98 \\
$\mathrm{Ni}$ & $0.50-2.00$ & $y=0.00008 x+0.0007$ & 0.999 & 0.002 & 0.006 & 0.62 & 94 \\
$\mathrm{~Pb}$ & $0.20-2.00$ & $y=0.00004 x+0.0004$ & 0.999 & 0.004 & 0.012 & 2.11 & 94 \\
\hline
\end{tabular}


(Szefer 2007). As a result, there were chosen nonparametric tests, i.e., the Spearman rank correlation and the Kruskal-Wallis test as well as factor analysis (FA) and cluster analysis (CA). All the calculations were made with the use of Statistica 10 program. All data were standardized and then elements were set as columns and tea samples as rows in the created data matrix.

The Kruskal-Wallis test and a series of preliminary FAs resulted in the elimination of elements from the dataset because of their negative impact on the diversification of samples in the final analysis. Finally, seven elements (K, P, Mn, Fe, Cu, $\mathrm{Co}$ and $\mathrm{Cd}$ ) were loaded onto the data matrix. In the CA, the best results were obtained with Ward's method using Euclidean distance.

\section{Results and discussion}

The concentrations of bioelements and toxic metals in the tea samples and percentages of leaching are listed in Table 3.

\section{Toxic elements}

Green tea from India had the lowest concentration of $\mathrm{Cd}$ $(0.003 \mathrm{mg} / 100 \mathrm{~g})$ and $\mathrm{Pb}(0.10 \mathrm{mg} / 100 \mathrm{~g})$ among the samples analyzed. Han et al. (2005) reported higher results for $\mathrm{Cd}(0.01 \mathrm{mg} / 100 \mathrm{~g})$. Moreda-Piñeiro et al. (2003) reported a concentration of $\mathrm{Pb}$ of $0.21 \mathrm{mg} / 100 \mathrm{~g}$ in Chinese teas, which was lower than the value obtained in the present study $(0.73 \mathrm{mg} / 100 \mathrm{~g})$. According to Santos et al. (2013), it can be explained by the variations

Table 3 Concentration of bioelements and toxic metals in tea samples in $\mathrm{mg} / 100 \mathrm{~g}(\bar{x} \pm \mathrm{SD}$, range) and percent of leaching (\%)

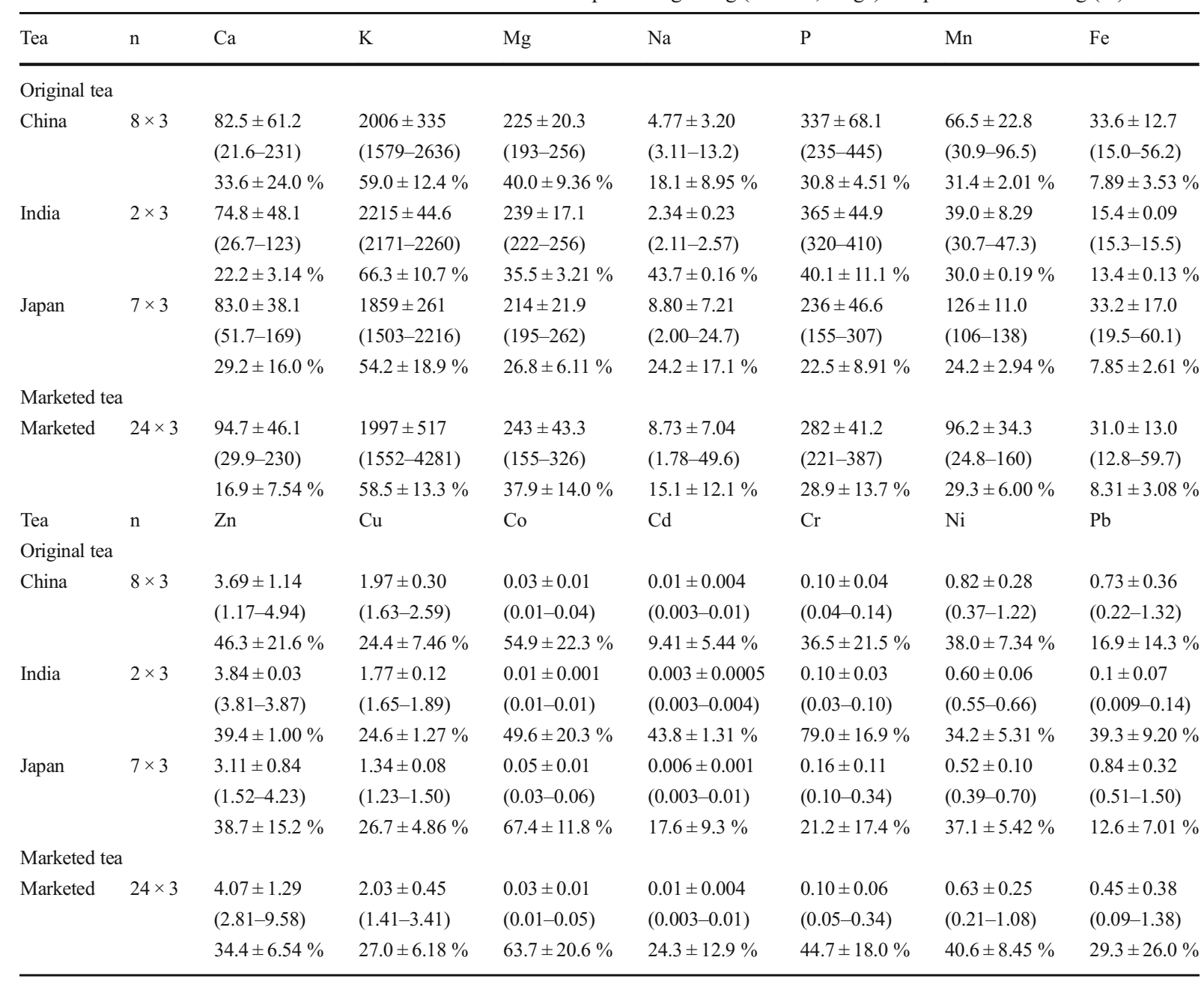

$n$ - number of samples multiplied by number of analytical subsample 
in $\mathrm{Pb}$ contamination sources of anthropogenic provenance, i.e., batteries, paints, dyes, and heavy industries. Moreover, Souza (2005) implied that $96 \%$ of lead in the atmosphere is of anthropogenic origin. What is more important, it was found that $\mathrm{Pb}$ is more bioavailable to tea plants growing in highly acidic soils (Han et al. 2006a, b). Shi et al. (2007) based on analysis of 328 tea samples for $\mathrm{Cd}$ (collected from the main teaproducing regions of China during the years 1997 and 1998) report $0.006 \mathrm{mg}$ of $\mathrm{Cd}$ in $100 \mathrm{~g}$. However, in 2004, the average Cd level increased to $0.01 \mathrm{mg} / 100 \mathrm{~g}$, which is comparable with our results. Such increase in $\mathrm{Cd}$ levels can be explained by tea contamination both by its accumulation in plants during the growth period and the manufacturing processes. According to the available literature, tea infusions were characterized with low $\mathrm{Cd}$ contents (Karak and Bhagat 2010). Indian teas had the highest percentage of Cd leaching (43.8\%) and Chinese tea had the lowest $(9.41 \%)$. Japanese tea had the highest $\mathrm{Pb}$ contamination $(0.84 \mathrm{mg} / 100 \mathrm{~g})$ and the percentage of leaching of this heavy metal amounted to $12.6 \%$ (Table 3). Few studies have assessed the concentration of $\mathrm{Pb}$ in tea infusions. Jin et al. (2005) observed a restricted leaching of $\mathrm{Pb}$ from tea leaves during soaking in boiling water. Karak and Bhagat (2010) suggested that there is a risk of exceeding the World Health Organization (WHO) limit set for $\mathrm{Pb}$ in drinking water $(0.05 \mathrm{mg} / \mathrm{L})$ by tea infusions (WHO 2003). Therefore, the contamination of tea leaves by $\mathrm{Pb}$ remains an issue of concern, and practices should be developed to avoid problems in the future.

\section{Macroelements}

Among the macroelements, $\mathrm{K}$ was present at the highest concentrations, with values of $2215 \mathrm{mg} / 100 \mathrm{~g}$ in Indian tea and $2006 \mathrm{mg} / 100 \mathrm{~g}$ in Chinese tea, which is in agreement with the results published by Kumar et al. (2005), Li et al. (2007), and Soomro et al. (2008). Such high concentrations might be explained, as Kumar et al. (2005) suggested, by the specific incorporation of K within a binding ligand of the tea leaves. However, concentration of $\mathrm{K}$ in Japanese brands was in the range of $1503-2216 \mathrm{mg} / 100 \mathrm{~g}$ with a mean content of $1859 \mathrm{mg} / 100 \mathrm{~g}$. According to Kumar et al. (2005), Indian and US tea brands contained between 1770 2400 and 1310-2370 mg K/100 g, respectively. Dambiec et al. (2013) found the lowest $\mathrm{K}$ content in tea from Argentina and Vietnam and the highest in samples from Central India. They reported that K concentration in tea is higher than $\mathrm{Mg}$, while the $\mathrm{Mg}$ content is higher than $\mathrm{Na}$ one. The differences in results concerning macroelements' contents obtained by various researchers depend on tea sample origins and conditions of their cultivations. According to Yemane et al. (2008), tea leaves, independently of their brand, contain higher levels of $\mathrm{K}$ than of $\mathrm{Na}$. Moreover, $\mathrm{Na}$ content, within different brands of tea, shows large variability (Kumar et al. 2005). Sodium is characterized by low concentrations, especially in Japanese $(8.80 \mathrm{mg} / 100 \mathrm{~g})$ and marketed tea $(8.73 \mathrm{mg} / 100 \mathrm{~g})$, which is comparable with values $(8.80 \mathrm{mg} / 100 \mathrm{~g})$ reported by McKenzie et al. (2010). According to Kumar et al. (2005), Na content varies widely $(2.1-11.8 \mathrm{mg} / 100 \mathrm{~g})$ in Indian tea brands, with a mean value of $5.35 \mathrm{mg} / 100 \mathrm{~g}$. However, US tea brands were characterized by a wider range of $\mathrm{Na}$ concentrations (11.4-79.6 mg/100 g) with a mean value of $33.8 \mathrm{mg} / 100 \mathrm{~g}$. Kumar et al. (2005) explained that US tea brands characterize with higher Na levels partially due to flavoring additives.

On the other hand, Varnam and Sutherland (1994) suggested that green tea character mainly depends on leaf compositions at the time of harvesting than on compounds formed during technological processing. Moreover, the elemental composition of green tea is strongly associated with its geographical origin (Marcos et al. 1998; Fernández-Cáceres et al. 2001; MoredaPiñeiro et al. 2003), genetic differences (Fung et al. 2003, 2009), soil composition, and agricultural or climatic conditions (Fung et al. 2003, 2009; Mehra and Baker 2007; Seenivasan et al. 2008b).

The determined percentage of extraction (Table 3) decreased in the following order: $\mathrm{K}(54.2-66.3 \%), \mathrm{Mg}$ (26.8-40.0\%), and P (22.5-40.1\%). Dambiec et al. (2013) also found that $\mathrm{K}$ is extracted to infusion to the greatest extent. They also noticed that percentage of leaching attributed to $\mathrm{Na}$ is the lowest among all the macroelements (Dambiec et al. 2013). However, in our study, Indian tea showed the highest percentage of extraction of $\mathrm{Na}(43.7 \%)$, whereas for other types of tea, it ranged between 15.1 and $24.2 \%$.

\section{Microelements}

Manganese was the most abundant microelement in the teas analyzed (39.0-126 mg/100 g), which confirms the suggestion made by Dambiec et al. (2013) that tea is a $\mathrm{Mn}$ accumulator. The concentration of $\mathrm{Mn}$ in marketed 
green tea $(96.2 \mathrm{mg} / 100 \mathrm{~g})$ was similar to that reported by Pohl and Prusisz (2007) (96.0 mg/100 g) and McKenzie et al. (2010) $(105 \mathrm{mg} / 100 \mathrm{~g})$. Indian tea had the lowest concentration of Mn $(39.0 \mathrm{mg} / 100 \mathrm{~g}), \mathrm{Fe}(15 \mathrm{mg} / 100 \mathrm{~g})$, $\mathrm{Co}(0.01 \mathrm{mg} / 100 \mathrm{~g})$, and $\mathrm{Cr}(0.10 \mathrm{mg} / 100 \mathrm{~g})$. Pękal et al. (2013) reported similar levels of elements such as $\mathrm{Fe}$ $(13.0 \mathrm{mg} / 100 \mathrm{~g})$ and $\mathrm{Cu}(1.80 \mathrm{mg} / 100 \mathrm{~g})$ for Indian green tea. Jin et al. (2008) and Mehra and Baker (2007) determined similar values for $\mathrm{Cu}$ in Chinese teas. The values reported by Mandiwana et al. (2011) for $\mathrm{Cr}$ in Chinese teas $(0.07 \mathrm{mg} / 100 \mathrm{~g})$ and Han et al. (2005) for Co $(0.04 \mathrm{mg} / 100 \mathrm{~g})$ were also comparable to those of the present study. Al-Othman et al. (2012) obtained comparable values for $\mathrm{Ni}(0.51 \mathrm{mg} / 100 \mathrm{~g})$ in marketed tea. Somewhat higher and comparable percentages of leaching in all green teas were noted for Mn (24.2$31.4 \%)$ and $\mathrm{Cu}(24.4-27.0 \%)$, which is also in accordance with the results of Pohl and Prusisz (2007) for the same marketed teas bought in Poland (Mn $22.0 \%$ ). Indian tea had a higher percentage of $\mathrm{Fe}$ leaching $(13.4 \%)$ than teas of other origins (ca. $8.00 \%$ ). The low Fe percentage of leaching may be explained by formation of complexes of low solubility (Soomro et al. 2008). Moreover, tannic acid as well as tannins reacts with elements in tea leaves, which might result in tea infusions' varied composition (Brzezicha-Cirocka et al. 2015; Powell et al. 1998). Precipitation of these chelates significantly decreases the concentration of metals in the brew extract. Dambiec et al. (2013) suggested that teas, which characterize with lower tannin levels, reveal better percentage of leaching of particular elements to infusions.

\section{Kruskal-Wallis test}

There was applied non-parametric test, i.e., the KruskalWallis test, which was used to evaluate the differences in mean concentrations between the tea groups from various geographical provenances in view of mineral composition (Herrador and González 2001; Fernández et al. 2002; Moreda-Piñeiro et al. 2003; McKenzie et al. 2010; Table 4). Based on the obtained results, it was concluded that elemental composition of tea is dependent on its country of origin. It was noticed that concentrations of such elements as $\mathrm{P}(\mathrm{H}=13.235 ; p=0.001)$, $\mathrm{Mn}(\mathrm{H}=10.557 ; p=0.005), \mathrm{Fe}(\mathrm{H}=13.235 ; p=0.013)$, $\mathrm{Cu}(\mathrm{H}=12.059 ; p=0.002)$, Co $(\mathrm{H}=8.809 ; p=0.012)$, $\mathrm{Cd}(\mathrm{H}=6.271 ; p=0.043)$, and $\mathrm{Cr}(\mathrm{H}=12.059$; $p=0.002$ ) are dependent on the geographical origin of samples. Comparable results of ANOVA Kruskal-Wallis test to our study were also obtained by McKenzie et al. (2010) who have reported that there are strong interdependences in tea samples for elements $\mathrm{Mn}, \mathrm{Cu}$, $\mathrm{Fe}$, and $\mathrm{P}$ in view of geographical origin. In addition, Moreda-Piñeiro et al. (2003) found statistically significant differences between $\mathrm{Fe}, \mathrm{Mn}$, and $\mathrm{Cu}$ for tea samples from China and India (Sri Lanka). According to Moreda-Piñeiro et al. (2003), it is possible to classify tea samples in view of their geographical provenance based on their mineral composition.

\section{Factor analysis}

Green tea purchased from tea shops appears to be appropriate ultimate datasets for FA, in which results are presented on Fig. 1a, b. There were two obtained factors, i.e., F1 and F2, that cumulatively explain $69.28 \%$ of the total variance $(\mathrm{F} 1=45.75 \%$ and $\mathrm{F} 2=23.53 \%)$. The eigenvalues for F1 and F2 amounted to 3.20 and 1.64 , respectively.

As shown in Fig. 1a, there were clear distinctions between samples from different regions such as China, India, and Japan. The scatterplot of loadings was drawn for F1-F2 to identify elements responsible for the grouping of objects (Fig. 1b). Higher F1 values for K, $\mathrm{Fe}$, and Co corresponded to Japanese and Indian samples, whereas lower values for $\mathrm{P}, \mathrm{Mn}, \mathrm{Cu}$, and $\mathrm{Cd}$ were characteristic of Chinese tea (Fig. 1a, b).

Regarding F2, samples were differentiated according to geographical origin mainly for Indian and Japanese teas. Lower F2 values were associated with Indian tea samples, and they overlapped partly with Chinese samples, which were identified mainly by their K content.

Table 4 The influence of the geographical provenance on elemental composition in view of ANOVA Kruskal-Wallis test

\begin{tabular}{lllllllllllllllll}
\hline Green Tea & $\mathrm{Ca}$ & $\mathrm{K}$ & $\mathrm{Mg}$ & $\mathrm{Na}$ & $\mathrm{P}$ & $\mathrm{Mn}$ & $\mathrm{Fe}$ & $\mathrm{Zn}$ & $\mathrm{Cu}$ & $\mathrm{Co}$ & $\mathrm{Cd}$ & $\mathrm{Cr}$ & $\mathrm{Ni}$ & $\mathrm{Pb}$ \\
\hline Geographical origin & $p$ & 0.93 & 0.30 & 0.27 & 0.20 & 0.001 & 0.005 & 0.01 & 0.34 & 0.002 & 0.01 & 0.04 & 0.002 & 0.07 & 0.07 \\
& $\mathrm{H}$ & 0.15 & 2.42 & 2.61 & 3.22 & 13.2 & 10.6 & 13.2 & 2.17 & 12.1 & 8.81 & 6.27 & 12.1 & 5.32 & 5.26 \\
\hline
\end{tabular}

$p$ level of significance, $H$ test value 


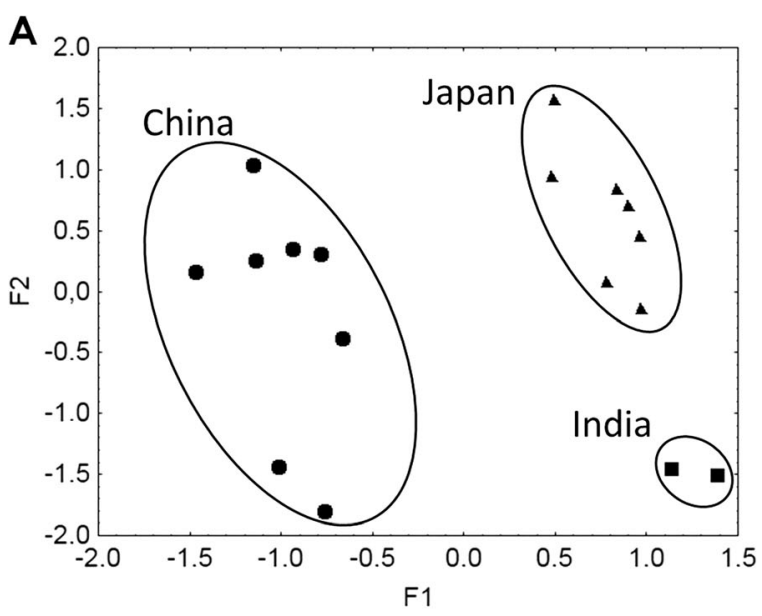

B

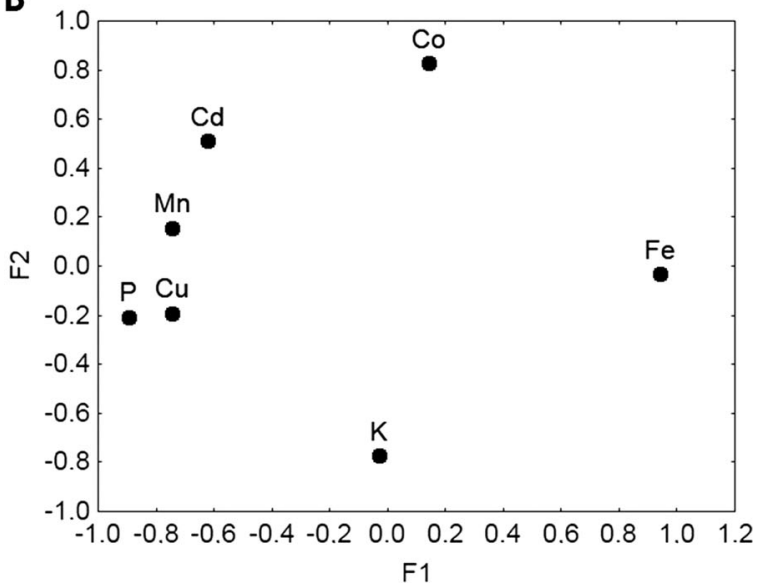

Fig. 1 a Scatterplot of the factors distinguishing green tea samples from various geographical origins. b Scatterplot of loadings for seven elements in green tea samples from various geographical origins

Higher scores were obtained for Japanese samples (overlapped partly with Chinese samples), which were identified by their Co content (Fig. 1a, b).

\section{Cluster analysis}

Figure 2 shows the dendrogram which was built with three main clusters containing samples from Japan, India, and China. As can be seen in this figure, CA enabled the differentiation of green tea samples according to geographical origin based on the chemical composition of the analyzed samples (Fig. 2).

These results suggest that CA, similarly to FA, can distinguish tea samples according to their geographical origin, which is important for the assessment of authenticity and fraud detection.
Recommended dietary intake

The WHO/FAO (2010) committee has set the PTWI for $\mathrm{Cd}$ at $7 \mu \mathrm{g} / \mathrm{kg}$, which recalculated for a person weighing $70 \mathrm{~kg}$ equals $490 \mu \mathrm{g} /$ person. However, the recommendation (PTWI) made for $\mathrm{Pb}$, which amounted to $25 \mu \mathrm{g} /$ $\mathrm{kg}$ of body weight, was retracted as it was found no longer health protective (WHO 2011). What is more, due to available scientific data, it was not possible to establish a new PTWI for Pb (EFSA 2010; WHO 2010).

The average $\mathrm{Pb}$ level in a $200-\mathrm{mL}$ beverage amounted to $0.002 \mathrm{mg} / 200 \mathrm{~mL}$, which means that one cup of green tea provided $0.11 \%$ of PTWI for $\mathrm{Pb}$, suggesting that consumption of green tea does not exceed the former PTWI recommendation for this metal. In case of $\mathrm{Cd}$, the mean content of this element in $200-\mathrm{mL}$ beverage was under the detection limits of the method applied $(\mathrm{Cd}<0.003 \mathrm{mg} / 100 \mathrm{~g})$; therefore, it was concluded that there is no health risk associated with green tea infusion consumption.

The RDAs for the different elements were calculated for green tea infusions according to the latest available Polish (Jarosz 2012) and American recommendations (American nutritional standards 2011). One cup of tea per day provide approximately $1 \%$ of the RDA for $\mathrm{Ca}$, $\mathrm{K}, \mathrm{Mg}$, Na, and $\mathrm{P}$, suggesting that green tea is not a rich source of macroelements in the daily diet (Table 5). Iron, $\mathrm{Zn}, \mathrm{Cu}$, and $\mathrm{Ni}$ provided approximately $1 \%$ of the RDA. However, green tea can be a good source of Mn. The percentage of the RDA provided by one daily cup of tea was approximately $28.3 \%$ for $\mathrm{Mn}$, which is significant; however, its bioavailability to the human body needs to be considered. According to Powell et al. (1998), almost $40 \%$ of $\mathrm{Mn}$ is bioavailable under simulated intestinal conditions, indicating that the RDA for $\mathrm{Mn}$ is reached in approximately $11.3 \%$ of cases through consumption of five cups of green tea. The highest RDA realization through consumption of one cup daily was recorded for Cr (2.86-4.00 \%). Seenivasan et al. (2008a, b) suggested that tea contamination by $\mathrm{Cr}$ originates mainly from soil but is also a result of CTC (crush, tear, curl) roller usage during tea processing. Mossion et al. (2008) implied that the percentage of elements leaching to infusions as well as the final composition of tea infusions is strongly dependent on water composition. Additionally, tea contains many anti-nutritive substances such as oxalate, which can absorb metals in solution. Taken together, our results suggest that drinking an average of five cups of green tea per day will not exceed the RDAs for the analyzed elements. 
Fig. 2 Hierarchical dendrogram of the analyzed original green tea samples as objects according to geographical origin
Ward's method

euclidean distance

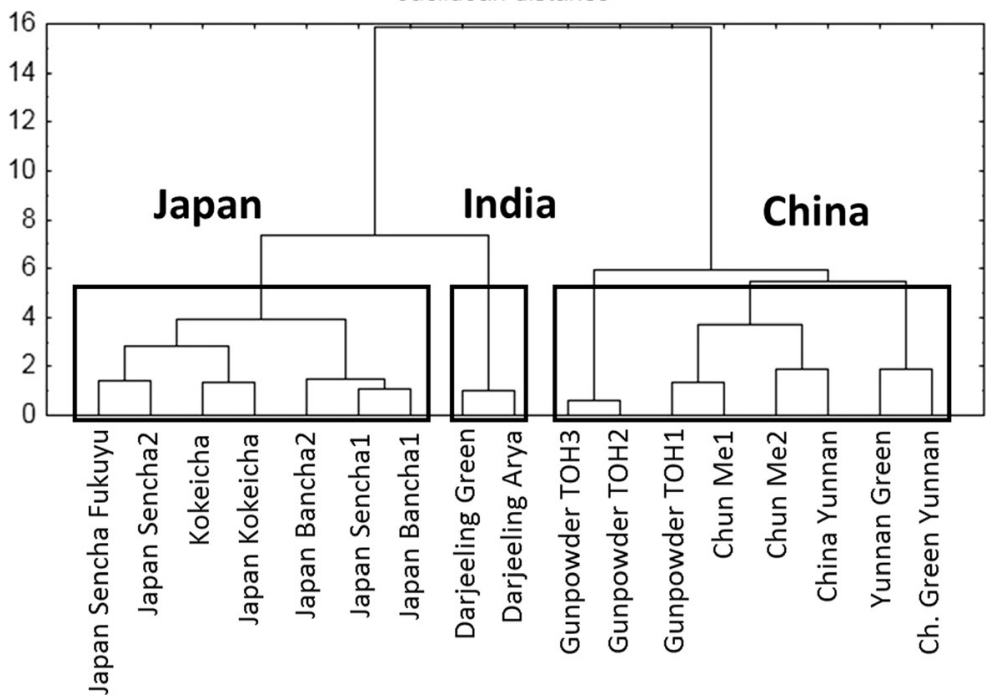

Table 5 Realization of recommended dietary intake through consumption of 1 cup of $200 \mathrm{~mL}$ green tea beverage

\begin{tabular}{|c|c|c|c|c|c|}
\hline \multirow[t]{2}{*}{ Element } & \multicolumn{2}{|c|}{$\begin{array}{l}\text { Recommended daily allowance (RDA) } \\
\text { [mg/day/person] }\end{array}$} & \multirow[t]{2}{*}{ Average content $(\mathrm{mg} / 200 \mathrm{~mL})$} & \multicolumn{2}{|c|}{$\begin{array}{l}\text { Realization of RDA through consumption of } 200 \mathrm{~mL} \text { of } \\
\text { infusion [\%] }\end{array}$} \\
\hline & $\begin{array}{l}\text { Males } \\
(31-50 \text { years })\end{array}$ & $\begin{array}{l}\text { Females } \\
(31-50 \text { years })\end{array}$ & & $\begin{array}{l}\text { Males } \\
(31-50 \text { years })\end{array}$ & $\begin{array}{l}\text { Females } \\
\text { ( } 31-50 \text { years })\end{array}$ \\
\hline $\mathrm{Ca}$ & 1000 & 1000 & $\begin{array}{l}0.35 \pm 0.34 \\
<\text { LOD }-1.54\end{array}$ & 0.03 & 0.03 \\
\hline K & 4700 & 4700 & $\begin{array}{l}23.4 \pm 9.08 \\
8.57-60.6\end{array}$ & 0.50 & 0.50 \\
\hline $\mathrm{Mg}$ & 420 & 320 & $\begin{array}{l}1.65 \pm 0.48 \\
0.85-2.72\end{array}$ & 0.39 & 0.51 \\
\hline $\mathrm{Na}$ & 1500 & 1500 & $\begin{array}{l}0.03 \pm 001 \\
<\mathrm{LOD}-0.05\end{array}$ & 0.002 & 0.002 \\
\hline$P$ & 700 & 700 & $\begin{array}{l}8.5 \pm 3.7 \\
1.3-16\end{array}$ & 1.21 & 1.21 \\
\hline $\mathrm{Mn}^{\mathrm{a}}$ & 2.3 & 1.8 & $\begin{array}{l}0.51 \pm 0.15 \\
0.18-0.86\end{array}$ & 22.2 & 28.3 \\
\hline $\mathrm{Fe}^{\mathrm{b}}$ & 10 & 18 & $\begin{array}{l}0.04 \pm 0.006 \\
0.04-0.07\end{array}$ & 0.40 & 0.22 \\
\hline $\mathrm{Zn}$ & 11 & 8 & $\begin{array}{l}0.03 \pm 0.01 \\
<\mathrm{LOD}-0.07\end{array}$ & 0.27 & 0.37 \\
\hline $\mathrm{Cu}$ & 0.9 & 0.9 & $\begin{array}{l}0.01 \pm 0.002 \\
<\mathrm{LOD}-0.01\end{array}$ & 1.11 & 1.11 \\
\hline $\mathrm{Cr}$ & 0.035 & 0.025 & $\begin{array}{l}0.001 \pm 0.0001 \\
<\text { LOD }-0.001\end{array}$ & 2.86 & 4.00 \\
\hline $\mathrm{Ni}$ & 1 & 1 & $\begin{array}{l}0.005 \pm 0.002 \\
<\text { LOD }-0.01\end{array}$ & 0.5 & 0.5 \\
\hline
\end{tabular}

LOD for $\mathrm{Ca}=0.02 \mathrm{mg} / 100 \mathrm{~g}$; LOD for $\mathrm{Na}=0.02 \mathrm{mg} / 100 \mathrm{~g}$; LOD for $\mathrm{Zn}=0.02 \mathrm{mg} / 100 \mathrm{~g}$; LOD for $\mathrm{Cu}=0.009 \mathrm{mg} / 100 \mathrm{~g}$; $\mathrm{LOD}$ for $\mathrm{Cr}=0.001 \mathrm{mg} / 100 \mathrm{~g} ; \mathrm{LOD}$ for $\mathrm{Ni}=0.002 \mathrm{mg} / 100 \mathrm{~g}$

${ }^{a}$ American recommendations (American nutritional standards 2011)

b Polish recommendations (Jarosz 2012) 


\section{Conclusions}

Assessment of the mineral composition of green tea is helpful to estimate the intake of toxic metals and bioelements associated with the consumption of infusions. Based on the FAO/WHO recommendations, we showed that consumption of green tea from China, Japan, India, and marketed tea is not associated with health hazards related to exposure to heavy metals such as Cd. Consumption of five cups of green tea per week does not pose a risk to human health. Comparison with the recent standards showed that green tea is characterized by high Mn levels.

The results of the present study suggest that chemometric techniques are very helpful tools for tea analysis and authenticity evaluation. These techniques enabled the differentiation of products according to geographical origin. Potassium, $\mathrm{P}, \mathrm{Mn}, \mathrm{Fe}, \mathrm{Cu}, \mathrm{Co}$, and $\mathrm{Cd}$ were found to be appropriate descriptors of tea samples' origin identification.

Open Access This article is distributed under the terms of the Creative Commons Attribution 4.0 International License (http:// creativecommons.org/licenses/by/4.0/), which permits unrestricted use, distribution, and reproduction in any medium, provided you give appropriate credit to the original author(s) and the source, provide a link to the Creative Commons license, and indicate if changes were made.

\section{References}

Al-Othman, Z. A., Yilmaz, E., Sumayli, H. M. T., \& Soylak, M. (2012). Evaluation of trace metals in tea samples from Jeddah and Jazan, Saudi Arabia by atomic absorption spectrometry. Bulletin of Environmental Contamination and Toxicology, 89, 1216-1219.

American nutritional standards. (2011). Food and Nutrition Board. Institute of Medicine, National Academies.

Brzezicha-Cirocka, J., Grembecka, M., \& Szefer, P. (2015). Oxalate, magnesium and calcium content in selected kinds of tea: impact on human health. European Food Research and Technology. doi:10.1007/s00217-015-2548-1.

Dambiec, M., Polechońska, L., \& Klink, A. (2013). Levels of essentials and non-essential elements in black teas commercialized in Poland and their transfer to tea infusion. Journal of Food Composition and Analysis, 31, 62-66.

EFSA. (2010). Scientific opinion on lead in food. EFSA Journal, 8, 1570. http:/www.efsa.europa.eu/fr/search/doc/1570.pdf. Accessed 02 Jan 2014.

FAOSTAT. URL http://faostat.fao.org/site/339/default.aspx. Accessed 02 Jan 2014.

Fernández, P. L., Pablos, F., Martin, M. J., \& González, A. G. (2002). Multi-element analysis of tea beverages by inductively coupled plasma atomic emission spectrometry. Food Chemistry, 76, 483-489.
Fernández-Cáceres, P. L., Martín, M. J., Pablos, F., \& González, A. G. (2001). Differentiation of tea (Camellia sinensis) varieties and their geographical origin according to their metal content. Journal of Agricultural and Food Chemistry, 49, 4775-4779.

Fung, K. F., Zhang, Z. Q., Wong, J. W. C., \& Wong, M. H. (2003). Aluminium and fluoride concentrations of three tea varieties growing at Lantua Island, Hong Kong. Environmental Geochemistry and Health, 25, 219-232.

Fung, K. F., Carr, H. P., Poon, B. H. T., \& Wong, M. H. (2009). A comparison of aluminum levels in tea products from Hong Kong markets and in varieties of tea plants from Hong Kong and India. Chemosphere, 75, 955-962.

Grembecka, M., \& Szefer, P. (2013a). Comparative assessment of essential and heavy metals in fruits from different geographical origins. Environmental Monitoring and Assessment, 185, 9139-9160.

Grembecka, M., \& Szefer, P. (2013b). Evaluation of honeys and bee products quality based on their mineral composition using multivariate techniques. Environmental Monitoring and Assessment, 185, 4033-4047.

Grembecka, M., Malinowska, E., \& Szefer, P. (2007). Differentiation of market coffee and its infusions in view of their mineral composition. Science of the Total Environment, 383, 59-69.

Han, W.-Y., Shi, Y.-Z., Ma, L.-F., \& Ruan, J.-Y. (2005). Arsenic, cadmium, chromium, cobalt, and copper in different types of Chinese tea. Bulletin of Environmental Contamination and Toxicology, 75, 272-277.

Han, W.-Y., Liang, Y.-R., Yang, Y.-J., Shi, Y.-Z., Ma, L.-F., \& Ruan, J.-Y. (2006a). Effect of processing on the $\mathrm{Pb}$ and $\mathrm{Cu}$ pollution of tea. Journal of Tea Science, 26, 95-101.

Han, W.-Y., Zhao, F.-J., Shi, Y.-Z., Ma, L.-F., \& Ruan, J.-Y. (2006b). Scale and causes of lead contamination in Chinese tea. Environmental Pollution, 139, 125-132.

Herrador, M. A., \& González, A. G. (2001). Pattern recognition procedures for differentiation of green, black and oolong teas according to their metal content from inductively coupled plasma atomic emission spectrometry. Talanta, 53, 1249-1257.

Jarosz, M. (2012). Normy żywienia dla populacji polskiejnowelizacja (In Polish). Warsaw: IŻŻ.

Jin, C.-W., He, Y.-F., Zhang, K., Zhou, G. D., Shi, J. L., \& Zheng, S. H. (2005). Lead contamination in tea leaves and nonedaphic factors affecting it. Chemosphere, 61, 726-732.

Jin, C.-W., Du, S.-T., Zhang, K., \& Lin, X.-Y. (2008). Factors determining copper concentration in tea leaves produced at Yuyao County, China. Food and Chemical Toxicology, 46, 2054-2061.

Karabagias, I., Michos, C., Badeka, A., Kontakos, S., Stratis, I., \& Kontominas, M. G. (2013). Classification of Western Greek virgin olive oils according to geographical origin based on chromatographic, spectroscopic, conventional and chemometric analyses. Food Research International, 54, 1950-1958.

Karak, T., \& Bhagat, R. M. (2010). Trace elements in tea leaves, made tea and tea infusion: a review. Food Research International, 43, 2234-2252.

Konieczka, P., \& Namieśnik, J. (2009). Quality assurance and quality control in the analytical chemical laboratory: a practical approach. Boca: CRC Press - Taylor \& Francis Group.

Kumar, A., Nair, A. G. C., Reddy, A. V. R., \& Garg, A. N. (2005). Availability of essential elements in Indian and US tea brands. Food Chemistry, 89, 441-448.

Li, T., Yu, L., Li, M., \& Li, W. (2007). Comparative studies on the qualities of green teas in Karst and non-Karst areas of 
Yichang, Hubei Province, PR China. Food Chemistry, 103, 71-74.

Mandiwana, K. L., Panichev, N., \& Pancheva, S. (2011). Determination of chromium (VI) in black, green and herbal teas. Food Chemistry, 129, 1839-1843.

Marcos, A., Fischer, A., Rea, G., \& Hill, S. J. (1998). Preliminary study using trace element concentrations and a chemometrics approach to determine geographical origin of tea. Journal of Analytical Atomic Spectrometry, 13, 521-525.

McKenzie, J. S., Jurado, J. M., \& Pablos, F. (2010). Characterisation of tea leaves according to their total mineral content by means of probabilistic neural networks. Food Chemistry, 123, 859-864.

Mehra, A., \& Baker, C. L. (2007). Leaching and bioavailability of aluminium, copper and manganese from tea (Camellia sinensis). Food Chemistry, 100, 1456-1463.

Moreda-Piñeiro, A., Fisher, A., \& Hill, S. J. (2003). The classification of tea according to region of origin using pattern recognition techniques and trace metal data. Journal of Food Composition and Analysis, 16, 195-211.

Mossion, A., Potin-Gautier, M., Delerue, S., Hécho, I., \& Behra, P. (2008). Effect of water composition on aluminium, calcium and organic carbon extraction in tea infusions. Food Chemistry, 106, 1467-1475.

Regulation (EU) No 1169/2011 of the European Parliament and of the Council of 25 October 2011. URL http://eur-lex.europa. eu/legalcontent/EN/TXT/?uri=uriserv:OJ.L_.2011.304. 01. 0018.01.ENG. Accessed 8 Aug 2015.

Official Methods of Analysis of AOAC International. (2002). Official method 991.25. Calcium, magnesium and phosphorus in cheese atomic absorption spectrophotometric and colorimetric method (17th ed.). Gaithersburg: AOAC International. Rev 1.

Pękal, A., Biesaga, M., \& Pyrzyńska, K. (2013). Trace metals and flavonoids in different types of tea. Food Science and Biotechnology, 22, 925-930.

Pohl, P., \& Prusisz, B. (2007). Fractionation analysis of manganese and zinc in tea infusions by two-column solid phase extraction and flame atomic absorption spectrometry. Food Chemistry, 102, 1415-1424.

Powell, J. J., Trevor, J. B., \& Thompson, R. P. H. (1998). In vitro mineral availability from digested tea: a rich dietary source of manganese. The Analyst, 123, 1721-1724.

Santos, L. F. P., Trigueiro, I. N. S., Lemos, V. A., Furtunato, D. M. N., \& Cardoso, R. C. V. (2013). Assessment of cadmium and lead in commercially important seafood from São Francisco do Conde, Bahia, Brazil. Food Control, 33, 193-199.

Sciubba, F., Capuani, G., Cocco, M. E., Avanzato, D., \& Delfini, M. (2014). Nuclear magnetic resonance analysis of water soluble metabolites allows the geographic discrimination of pistachios (Pistacia vera). Food Research International, 62, 66-73.

Seenivasan, S., Manikandan, N., \& Muraleedharan, N. N. (2008a). Chromium contamination in black tea and its transfer into tea brew. Food Chemistry, 106, 1066-1069.

Seenivasan, S., Manikandan, N., Muraleedharan, N. N., \& Selvasundaram, R. (2008b). Heavy metal content of black teas from south India. Food Control, 19, 746-749.

Shen, F.-M., \& Chen, H.-W. (2008). Element composition of tea leaves and tea infusions and its impact on health. Bulletin of Environmental Contamination and Toxicology, 80, 300-304.

Shi, Y. Z., Jin, L. M., \& Zhu, Y. S. (2007). The contents status quo and the accumulation characteristic of heavy metal in tea. China Tea, 6, 17-19.

Soomro, M. T., Zahir, E., Mohiuddin, S., Khan, A. N., \& Naqvi, I. I. (2008). Quantitative assessment of metals in local brands of tea in Pakistan. Pakistan Journal of Biological Sciences, 11, 285-289.

Souza, N.R. (2005). Evaluation of training piromorfite in soils contaminated with $\mathrm{Pb}$ through infrared spectroscopy (in Portuguese). M. Sc. Thesis, Universidade Estadual: Paulista.

Szefer, P. (2007). Chemometric techniques in analytical evaluation of food quality. In P. Szefer \& J. O. Nriagu (Eds.), Mineral components in foods (pp. 70-111). Boca Raton: CRC Press Taylor \& Francis Group.

Szymczycha-Madeja, A., Welna, M., \& Pohl, P. (2012). Elemental analysis of teas and their infusions by spectrometric methods. Trends in Analytical Chemistry, 35, 169-171.

Varnam, A. H., \& Sutherland, H. P. (1994). Beverages: technology, chemistry and microbiology (pp. 126-189). UK: Chapman and Hall.

WHO. (2003). Lead in drinking-water, background document for preparation of WHO Guidelines for drinking-water quality. Geneva: World Health Organization.

WHO (2010) Seventy-third report of the Joint FAO/WHO Expert Committee on Food Additives. URL http://whqlibdoc.who. int/trs/WHO_TRS_960_eng.pdf. Accessed 30 Jan 2015.

WHO. (2011). Lead in drinking-water, background document for preparation of $W H O$ guidelines for drinking-water quality. Geneva: World Health Organization. URL: http://www.who. int/water_sanitation_health/dwq/chemicals/lead.pdf. Accessed 30 Jan 2015.

Yemane, M., Chandravanshi, B. S., \& Wondimu, T. (2008). Levels of essential and non-essential metals in leaves of the tea plant (Camellia sinensis L.) and soil of Wushwush farms, Ethiopia. Food Chemistry, 107, 1236-1243. 